\title{
ANGELS IN THE TRENCHES: BRITISH SOLDIERS AND MIRACLES IN THE FIRST WORLD WAR
}

\author{
by KATHERINE FINLAY
}

I $\mathrm{N}$ their interactions with the soldiers during the First World War the British military chaplains were afforded the opportunity to see the Christian body in microcosm. ${ }^{1}$ The chaplains' frontline experiences shaped their positions on popular religion and the sincerity of Christian belief and practice amongst Britain's youth. ${ }^{2} \mathrm{~A}$ comparative assessment of clerical responses to soldiers' claims of the miraculous not only demonstrates a critical divide in clerical understanding of the supernatural - a divide which is more appropriately separated along theological rather than denominational lines. It also indicates that many of the differences between Catholic and Protestant evaluations of popular religion were, fundamentally, differences of clerical perception rather than popular practice and belief. ${ }^{3}$

To a greater extent than Protestants, Catholics maintained not only that miracles and wonders had occurred previously but that they still had relevance in the modern world. ${ }^{4}$ Both Anglo- and Roman Catholic teaching emphasized the importance of accepting 'miraculous' occurrences which took place in the routine life of Catholics, namely in the sacraments and through the assistance offered by saints and angels. ${ }^{5}$ For Roman Catholics this position was affirmed even more firmly when, in response to challenges created by modern science and philosophy, the

See especially D. S. Cairns, The Army and Religion (London, 1919); Charles Plater, ed., Catholic Soldiers (London, 1919); Anon., Catholics of the British Empire and the War (London, I916); Arthur Herbert Gray, As Tommy Sees Us: a Book for Church Folk (London, 1917) and Stephen H. Louden, Chaplains in Conflict: the Role of Army Chaplains since 1914 (London, 1996).

2 See Alan Wilkinson, The Church of England and the First World War (Ist edn, London, 1978; 2nd edn, 1998), 169-96; Albert Marrin, The Last Crusade: the Church of England in the First World (Durham, NC, 1974), I 35-42; Alan Wilkinson, Dissent or Conform?: War, Peace and the English Churches 1900-1945 (London, 1986), 33-6; Stuart Mews, 'Religion and English Society in the First World War', unpublished Ph.D. thesis, University of Cambridge, I973, 173-87; Thomas Johnstone and James Hagerty, Cross on the Sword: Catholic Chaplains in the Forces (London, I996), I00-90; Adrian Hastings, History of English Christianity 1920-1990 (London, 1991), 30-I 40.

3 Michael Snape, 'British Catholicism and the British Army in the First World War', Recusant History 26 (2002), 354-52, and Wilkinson, Church of England, 1 53-68.

4 See Mary Heimann, Catholic Devotion in Victorian England (Oxford, I995), 33.

5 Ibid., IIs. 
Vatican rejected Modernism in the Syllabus of Errors ( 1856 ), preferring instead a more conservative approach to scientific advances and also a more literal interpretation of supernatural events recorded in the Bible. ${ }^{6}$ Because Catholic teaching maintained these clear lines regarding supernatural phenomena, Catholic clergy had an established means by which to test the validity of claims to the miraculous. ${ }^{7}$ Therefore, when confronted with claims about miracles, even while Catholic priests questioned the legitimacy of individual cases, they also had a system by which to assess, and thus the capacity more willingly to accept, the possibility of supernatural assistance.

Protestants varied widely in their views of the miraculous but most non-Catholics did not maintain a strong devotion to saints or guardian angels and they tended to recognize the symbolic value rather than the actual efficacy of sacramental and religious assistance. ${ }^{8}$ While accepting that heaven and earth were in some ways related, most Protestants did not tend to make this link as easily as Catholics did, and the Protestant Churches did not have a coherent system by which they could establish this link definitively. Amongst some Protestants there also existed a growing scepticism with regard to supernatural events recorded in the Bible; the bodily resurrection of Christ and the Virgin Birth were both called into question by some theologians. ${ }^{9}$ Most Protestants did not adopt this more extreme theological stance but they nevertheless had fewer points than Catholics by which they could legitimately connect the natural with the supernatural..$^{10}$ The supernatural was, therefore, not only considered inexplicable but was recognized as extraordinary, and most Protestant clergy did not believe that supernatural intervention occurred on a regular basis.

Although their Churches' positions on supernatural intervention differed from one another, both Catholic and Protestant soldiers made claims of supernatural experiences during the war. These typically took one of three forms: (I) miraculous intervention by an angel or saint;

6 See Sheridan Gilley and W. J. Shiels, A History of Religion in Britain: Practice and Belief from Pre-Roman Times to the Present (Oxford, I 994), 278.

7 J. Derek Holmes, More Roman than Rome: English Catholicism in the Nineteenth Century (London, 1978), 13-47.

8 Terence Thomas, The British: their Religious Beliefs and Practices (London, I988), 64.

9 Ibid., 63-4. William Sanday and Hensley Henson were two of the more controversial proponents of these ideas. See The Church Times, 2 I December 1917,538 for the debate surrounding Henson's beliefs.

10 A. E. J. Rawlinson, Authority and Freedom: the Bishop Paddock Lectures for 1923 (London, 1924), 97, and H. Horne, ed., Chaplains in Council (London, I917). 


\section{Miracles in the First World War}

(2) miraculous protection by an object of piety or religious significance; and $(3)$ miraculous protection given to a religious image. In their interactions with the soldiers, both Catholic and Protestant clergy were required to consider the legitimacy of the miraculous claims which were made. Their responses to these claims were affected not only by the subjective credibility of the claim made and the person who made the claim, but also by the cleric's own understanding and level of acceptance of supernatural workings in the Christian life.

Although chaplains tended to view miraculous claims with at least some degree of scepticism, both Protestants and Catholics could in theory accept the possibility of the individual miracles which soldiers at the front claimed to have experienced or witnessed. The Anglican chaplain, E. E. Hayward noted that the trenches seemed to contain 'an inexhaustible amount of mystery and revelation' which came in 'dribblets by way of communicative patients' to the chaplains who were serving at the front. ${ }^{11}$ Careful scrutiny had to be applied, but some claims of miraculous assistance were accepted as legitimate by some Protestants. In I917, Reverend Montague Bere wrote of a soldier whom he met in hospital, whose miraculous claims appeared to Bere to be quite convincing. This man claimed that he had been accompanied in battle by what Bere labelled a 'Friend in White'. According to the soldier, when he and two other soldiers had been lying in a shell-hole in an attempt to escape machinegun fire, 'a fourth came and lay with them' and this Friend put his hand on the head of the one who had come to the hospital'. ${ }^{12}$ After further inquiry, Bere said of the man:

I find him a sergeant with DCM - a very fine specimen indeed. He held a position for twenty-four hours single-handed at the end, all his 2 I men being laid out. In the night he had to sit on a dead officer and he so managed his bombs and machinegun and rifle that the enemy thought the position strongly held. So he is not the sort to see hallucinations, and he says his 'Companion' has never left him when he has been under fire. ${ }^{13}$

Although Bere did not claim to understand the man's story nor did he have a specific framework in which to fit such an idea, it is notable that he did acknowledge the legitimacy of the man's claim and the possi-

11 Imperial War Museum, First World War Collection, 'Religion', E. E. Hayward file, Hayward to his aunt, I 4 October, 1916.

12 Ibid., Montague Bere file, Bere to his sister, 29 March 19 I 7.

13 Ibid., 30 March I9I7. 
bility of supernatural assistance. It is equally significant that Bere based his assessment on his belief that the man seemed capable of discerning reality from imagination rather than on criteria set by his Church.

The difficulty of assessing miraculous claims was particularly obvious in I9I4, when Protestants and Catholics debated whether or not they should accept the popular claim that angels came to the aid of the British soldiers during the first battle of Mons. The most challenging aspect in this matter was that Arthur Machen, an occultist and novelist known for his tales of supernatural horror, claimed that he had written the story of such miraculous intervention in his fictional work, The Bowman, even before the story of Mons became popular. Although there was widespread scepticism amongst both Catholics and Protestants, a number of chaplains were willing to accept the possibility that a miracle had occurred in Mons. The Evangelical chaplain Reverend Bulstrode asserted that he believed that Angels were in Mons whether the angels had been seen or not. ${ }^{14}$ A correspondent for the AngloCatholic organ, The Church Times, asserted:

So many people have given their accounts that it happened, it must be true. If God is ever going to help out a people, it will be now when the English are so obviously in the right. It has happened before when the archangel Uriel destroyed the hosts of Sennacharib. ${ }^{15}$

After asserting this, however, this correspondent also acknowledged that while there was much to be said in support of such possibilities there was also, 'a good deal to be said on the other side'. He noted that although many people claimed to have seen the angels, their experiences did not validate the event. However, he also asserted that the simple fact that the angels were not seen by all of the men did not discount the possibility that they had been present.

Such a dilemma brought to the fore the basic questions which were being asked at the time, namely, whether or not specific miracles took place, whether or not the miraculous or supernatural forces were real and active factors in modern experience and if so, by what means miracles could be validated and distinguished from fanciful stories. ${ }^{16}$ The heart of these questions as well as the difference between Catholic and

14 Ibid., Bulstrode file, Bulstrode diary, p. 47.

15 The Church Times, 9 July I $915,47$.

16 See Wilkinson, Church of England, 194-5. 
non-Catholic belief were considered by a correspondent in The Church Times who asserted that to a Catholic who prayed 'at Michaelmas that the angels may "Succour and defend us on earth", the primary concern was not whether or not angels were at the battle or even whether people had seen the angels; Catholics accepted that angels were certainly present at the battle since they were always present and watching over their charges. Thus, the question was really whether or not the angels had intervened in any particular way during this battle. ${ }^{17}$ This particular topic was dealt with by a Roman Catholic homilist at $\mathrm{St}$ Dominic's Priory, Haverstock Hill, who asserted:

It is not the question whether anyone caught a glimpse of them with his eyes, or a sound with his ears. It is above sense, greater than sense. Sense may fail, but faith remains.... Our traditions are greater than our past, and today our facts are greater than our traditions. But because we believe, independently of the words and visions of men, and know the angels are there, and because we can commit everyone that falls to God knowing that for each there is an angel that is guarding, for us there must be never a failure, never a triumph, but the will of God alone. ${ }^{18}$

In part because Catholics recognized the presence of the supernatural in normal, everyday settings, they also distinguished general acceptance of the supernatural from instances of specific miraculous intervention. Thus, when considering the possibility of angels appearing at Mons, Stephen Rawlinson, the Senior Catholic Chaplain in France, wrote to General French saying:

The direct question is - was there supernatural intervention at Mons? A man writes to the Daily Mail and says it is a fiction invented by himself; on the other hand we had a man in Birkenhead (Private Cleaver) who was himself at Mons and saw the Angels. ${ }^{19}$

Given the ambiguous nature of the matter, Rawlinson suggested that the army should find 'six men of good character' who had all claimed to have seen the angels to sign an affidavit in which they attested to the experience they had at the front. Although sceptical, he concluded by

17 The Church Times, 13 August $1915,148$.

18 The Tablet, 28 August I9 I $5,286$.

19 Downside Abbey, Rawlinson Collection, Letters I9I5-1917, Rawlinson to General French, is August I9I s. 
saying: 'If this manifestation has actually occurred, it is the most glorious and sublime event since the day of Pentecost; what a grand uplift would the firm assurance of it give to the religious life of England! 20

This broader acceptance of, as well as the more systematic way of testing the validity of claims about the supernatural was particularly critical in distinguishing Catholic from Protestant approaches. The difference was based largely on the fact that Catholics so thoroughly accepted the relationship between the natural and the supernatural that they had a coherent system of assessing claims of supernatural intervention and miracles. ${ }^{21}$ Protestants, by contrast, were willing to accept the idea that miracles could occur, but they did not have such a clearly established framework by which to assess the miraculous. In his wartime diary the Anglican chaplain, E. C. Crosse, articulated the difficulty of this discernment in practical terms, saying that, at the front: 'Mere hatefulness of the place caused men to fall back on God as 'some sort of guardian angel'.22 However, he also indicated the superstitious and ineffectual nature of this belief, saying that after having spent some time at the front, most men exchanged their idea of providence for more fatalistic positions. ${ }^{23}$ It is understandable, then, that Protestants could not approach the particular questions of Mons in a united or coherent way; they would have had to agree first more generally about what constituted a miracle, how to validate supernatural experience and how to separate the supernatural from the superstitious.

The difference between the Catholic and non-Catholic position can be seen even more obviously when examining the approaches of British Christians to miraculous claims involving individual guardian angels. Although some Protestants were willing to accept the extraordinary claims surrounding the angels of Mons, Wilfred Monod presented the uniquely Catholic understanding of protecting angels at the Oratory in Paris in I9I4. He claimed that the soldiers in France were:

... Surrounded by a great cloud of witnesses - an invisible legion of Guardian Angels. ... The Chevaliers of Fire commune with our own, they espouse their cause, they identify themselves with them

20 Ibid.

21 See H. Atteridge, Army Chaplains in the Great War (London, 1916).

22 Imperial War Museum, First World War Collection, 'Religion', E. C. Crosse file, E. C. Crosse, unpublished war diary, n.p.

23 Ibid. 


\section{Miracles in the First World War}

in the kingdom of the Spirit, so that they become mystically inseparable. Lord, open Thou our eyes that we may see them. ${ }^{24}$

Such ideas were generally accepted within Catholicism and were the basis by which both Roman and Anglo-Catholics understood and practised their faith. Indeed, the Belgian primate, Cardinal Mercier even maintained that in Catholicism the Church was not divided in two with part of the Church on earth and the other part in heaven. Rather, he claimed that there was only one Church which passed through two distinct phases: "What the elect see, we believe, what they possess we hope for, those whom they love, God, Christ and His Mother the Angels and saints we also love; humbly no doubt but with a love like theirs'. ${ }^{25}$

This difference was further demonstrated in the positions maintained by Catholics and Protestants with regard to whether or not divine aid was available to specific individuals who prayed for the intercessions of angels or saints. For instance, one Catholic soldier credited his miraculous escape to the Sacred Heart and Mary saying that they had brought him safely home: 'I am as sure of that as I am of this morning's daylight. My little son offered his first Communion to bring his daddy back, and his little prayer was answered'. ${ }^{26}$ The presence of Christ in the Eucharist was also recognized by Catholics as a means of miraculous assistance. Father Willie Doyle told of one occasion when he knew that his regiment was waiting in a village for him to say Mass and that many of them would be going to the trenches in the afternoon. If he did not turn up, they would lose the chance of Confession and Holy Communion, but the only way to reach them was by means of a 'shell swept road'. Given the sacramental needs of the men, he decided to go. He said of the experience:

Call it a miracle if you will, but the moment I turned the corner, the guns ceased firing, and not a shell fell until I was safely in the village church. My confidence in God's protection was not misplaced. ${ }^{27}$

Many Protestants would not have chosen to call this a miracle. This was in part because of their understandable scepticism regarding specific miracles. However, it was also in part because they had no established

24 George Bedborough, Arms and the Clergy, 191 4-1 918 (London, I934), 77.

5 Cardinal D. J. Mercier, The Voice of Belgium (London, 1917), 55.

26 The Tablet, 26 August 1916, 268.

27 E. M. G., A Brave Soldier (Melbourne, 1942), 20. 
means by which to assess the nature of divine assistance nor did they have a position regarding the nature of God's presence in the sacraments and objects of religious devotion which was accepted across the range of Protestant Christianity.

This difference was also evident in the ways in which Catholics and Protestants regarded devotional aids. Because of their belief in the miraculous benefits of the saints and the sacraments, Catholics were encouraged to carry rosaries, devotional badges, scapulars and medals. Although the men believed that these could offer protection and this at times crossed over into superstition, Catholics accepted that this was not entirely problematic. A respondent to Catholic Soldiers justified this saying:

It is probable that many Catholic soldiers are content to carry their rosaries about with them, seldom or never 'saying' them. And no doubt the 'souvenir' or 'keepsake' idea often comes in. Yet seldom, if ever, is the rosary regarded, even by an ill-instructed Catholic, merely as a charm or mascot. It is certainly looked upon as "protective' but this through the intercession of the Mother of God in whose honour the rosary is carried. ${ }^{28}$

When viewed in such a way, medallions and amulets were seen as aids to Christian devotion rather than objects of worship. This idea did not extend to the Protestant Churches. Although Protestant chaplains were willing to accept the possibility of miracles, miraculous badges and images which were specifically intended for the protection and assistance of their possessors were regarded as items of superstition even when they carried some religious significance. ${ }^{29}$ In some instances, non-Catholics even questioned the orthodox use of pious aids by Catholics. In response to this scepticism, the Catholic chaplain Henry Day defended the orthodox use of devotional aids, saying that his men were not merely 'fond of decorations' but that they were 'Soldiers of Christ and Our Lord as well as soldiers of the King., ${ }^{30}$

Just as Catholics claimed that God provided protection for people who carried devotional aids, they also claimed that God offered specific protection to religious statues and crucifixes. In one area of the front, a statue of Mary had not only escaped a bombardment but stood with an

30 Atteridge, Army Chaplains, I 8. 


\section{Miracles in the First World War}

unexploded shell lying next to it. This statue was regarded with such awe that some men in that region erected a shrine overlooking the battlefield in honour of the statue. ${ }^{31}$ After seeing a crucifix at Loos which had been preserved in a similarly extraordinary fashion, Father William Doyle noted in his war diaries: 'Surely if the Almighty can protect the image of His Son, it will be no great difficulty to guard His priest also, as indeed He has done in a wonderful way'. ${ }^{32}$

Non-Catholics also took notice of such images. For instance, the soldier-turned-author, Talbot Kelly, was impressed by a crucifix in Montauban, of which he noted: 'By a great heap of rubble that must have been the Church stood an almost untouched crucifix'. ${ }^{33}$ Non-Catholics were as taken as Catholics by the famous leaning Virgin of Albert; this was a statue of Mary which had crowned the church in the village of Albert, but which had been shelled so that it stood at an angle over the town, with the Baby Jesus suspended precariously above the village. The Protestant soldier, G. V. Dennis, spoke of a time when he went to Albert, noting how the myths surrounding the statue were inconsistent. Upon arrival in the town he discovered that the French believed that the war would end in a German victory if the leaning Madonna fell from her position and that, because of this, she had been secured with steel cables. He lamented this action since, as he recorded, the English soldiers had always heard that the war would end with an allied victory if the statue were to fall. ${ }^{34}$ Because of such interest in these religious images, Army and Religion, the wartime poll about religious beliefs in the army, noted with some optimism:

Men have noticed the crucifixes they have passed in France. It is a symbol which they like. It bears possibilities. Not much is yet attached to it, but it is the Crucified Christ rather than the Risen Christ which appeals. ${ }^{35}$

Questions about the significance which should be attached to these figures and whether miracles could be assigned to them was, however, still a basic matter of debate for Protestants. While it was clear that

31 Stonyhurst Magazine (February I 9 17), I 834.

32 Alfred O'Rahilly, Mattyr Priest: the Life and Death of Father William Doyle S.J., Who Died in the 'Great War', ed. John Harney (Limerick, 1998), 27.

33 R. B. Talbot Kelly, A Subaltern's Odyssey: Memoirs of the Great War, 191 5-1 917, ed. R. G. Loosmore (London, 1980), 93.

34 Imperial War Museum, First World War Collection, 'Religion', D. V. Dennis, File, 'A Kitchener Man's Bit', unpublished war memoir, I928.

35 Cairns, Army and Religion, 42. 


\section{KATHERINE FINLAY}

people were affected by the Christian images and crucifixes which survived, there was no consensus amongst Protestants about what this meant for Christian faith more broadly. Because Protestant teaching had no established place where supernatural assistance could be evaluated, Protestants were left to assess miraculous claims by means of their private judgement. This ambiguity resulted in the very careful approach and general wariness of Protestant clergy to claims to miracles which were made by the men.

The place of Christian symbols and the relationship between the natural and supernatural was much more clearly defined for Catholics as can be seen in the Catholic responses to the leaning Virgin in Albert. In a letter which was written to The Tablet one correspondent claimed:

Thousands have read of the wonder of the great statue of the Virgin and Child that once crowned the tower of the basilica at Albert, and that still hangs out horizontally from its base over the town. Albert, its church and hospital were shelled by the Germans in the autumn of $19 \mathrm{I}_{4}$, and a religious of the hospital visiting the place in February of last year thus describes what she saw: 'It is Jerusalem in ruins, but dominated by Mary, who seems to show these ruins to her Divine Son. ${ }^{36}$

This sense of reality was a distinguishing characteristic of the Catholic approach to objects of religious piety and the closeness with the supernatural made Catholics more accepting of the possibility of miracles.

As seen in these several examples, both the different ways in which Catholics and non-Catholics understood the supernatural in terms of their theological positions, as well as the ways in which the Churches dealt with the inexplicable, played into the different responses which Catholics and non-Catholics had towards claims about miracles at the front. Although beliefs were important on a personal level, the frameworks in which the Churches had to deal with those beliefs proved to be equally influential in shaping the British clerical understanding of miracles during the First World War.

Wolfson College, Oxford

36 The Tablet, ig August i9 16, 229. 